UDC 664.38

DOI https://doi.org/10.32838/2663-5941/2021.2-2/22

Nan Haijuan

Sumy National Agrarian University

Li Bo

Henan Institute of Science and Technology

Stepanova T.M.

Sumy National Agrarian University

\title{
RELEVANCE OF CULTIVATED MUSHROOMS USAGE IN FOOD AND PERSPECTIVES IN SAUSAGE PROCESSING
}

The article is devoted to the study of the relevance and prospects of the use of cultivated mushrooms in food in general and sausage production in particular. The mushroom production in China is growing fast. Due to the rich nutrition and health functions, mushrooms are favored by many consumers.

The article draws attention, that functional ingredients of mushrooms, as protein, polysaccharides, polypeptide, amino acids and triterpenes can be made into nutraceuticals. The abundant protein in mushrooms has good antioxidant, antitumor and immunomodulatory activities. There are many studies on the extraction, structure and functional characteristics of mushroom polysaccharides, peptides and protein, some of them have been commercialized as health products.

Mushrooms have been widely used in food because of their unique taste, flavor, high nutritional value and health benefits. The most common processed products of mushrooms are dry products and canned, pickled, sugar products.

Mushrooms are rich in nutrients and are known as "plant meats" and have become a trend food. In can be also introduced "vegan steak". It was made entirely of mushrooms, has no meat and very popular locally. In China the eating mushrooms daily are considered a healthy diet.

Adding mushrooms to sausages can replace meat proteins and fats and has antioxidant effects. Thanks to a rich polysaccharides and polyphenols content, mushrooms can increase sausage oxidation stability. Mushrooms are a good and economical alternative to meat protein in sausage. Mushrooms can also make into a variety of beverage and seasoning. Adding mushrooms to foods to increase the flavor and nutritional value of the food is also one of the usage of mushrooms. Sausages using mushrooms as the main raw material will be an important application for mushroom in the future and have a good perspective.

Key words: cultivated mushrooms, nutritional value, nutraceuticals, functional polysaccharides, sausage.

Formulation of the problem. China is the country with the fastest growth in mushroom production in the world. The growth rate is far higher than the world average, accounting for a quarter of the world's mushroom production and the total mushroom production in 2019 reach 39691 million tons. However, the current level of mushroom processing technology is relatively backward, more primary products, less product varieties and fewer high value-added products, which leads to increasingly prominent contradictions in production and sales [1].

Edible fungus commonly known as mushroom refers to a large fungus whose fruiting body is larger and edible. There are two types of mushrooms: edible and medicinal [2]. Common edible mushrooms include Pleurotus ostreatus, Shiitake mushroom, Flammulina velutipes, Pleurotus eryngii, Agaricus bisporus, Coprinus comatus, Straw mushroom, Tre- mella fuciformis, Agaric. Mushrooms are delicious and contain many flavor substances [3]. They are rich in proteins, amino acids, polysaccharides, dietary fiber, unsaturated fatty acids, nucleosides, mineral elements, and a variety of physiologically active substances, such as antioxidants ergothioneine, glutathione and $\beta$-glucan.

Mushrooms have important antioxidant effects [4]. The water extract and alcohol extract of Coprinus comatus have certain clear ability to 2,2-diphenyl1-picryl-hydrazyl-hydrate (DPPH) radical, superoxide anion, hydroxyl radical, etc. [5] and also have hypoglycemic [6], antitumor and immunomodulatory effects [7], protective effects on the cardiovascular system [8], antibacterial, anti-inflammatory, weight loss and other medical care functions [9].

The incidence of obesity, diabetes, coronary heart disease and malignant tumors has remained high with 
the development of modern material civilization. So, concepts of people nutrition and health care are undergoing significant changes. People's pursuit of nutrition and health food is growing stronger. Due to the rich nutrition and health functions, mushrooms are favored by many consumers. Much research has focused on the development of mushroom products. Nowadays mushrooms are widely used in food industry, and consumers can purchase their favorite mushroom products from the market [4].

Analysis of recent research and publications. Mushrooms have the high moisture content and short storage period, in order to achieve long-term preservation, edible fungi are often made into dry products by simple different drying methods [10] and are often processed simply into canned, pickled, sugar products. So, simple processing is currently the main form of mushroom processing. These methods can better maintain the original shape and flavor of the mushrooms, meanwhile increase the visibility of the product. The simple form of processing makes mushrooms safer, convenient and hygienic to eat [11].

Functional ingredients such as protein, polysaccharides, polypeptide, amino acids and triterpenes in mushrooms can be made into nutraceuticals. There are many studies on the extraction, structure and functional characteristics of mushroom polysaccharides, peptides and protein, some of them have been commercialized as health products [12].

Mushrooms are rich in polysaccharides. They have the function of anti-tumor and enhancing immunity. Nowadays, the biological effect of immune polysaccharides in mushrooms are getting more and more attention. Most of the polysaccharides in mushrooms were extracted and separated by water solution and alcohol extraction, which greatly improved the value of mushrooms and was the hotspot of current research [12-13]. Flammulina velutipes polysaccharide nanoparticles have great application potential in the food industry, such as emulsifiers, enhancers and bioactive carriers [14]. The stem of Pleurotus ostreatus contains more insoluble dietary fiber than the cap and is a valuable source of cell wall glucan, which can be used to prepare food additives.

Mushrooms are rich in amino acids. Various amino acids will form unique flavor polypeptides. These are the unique flavor substances of various mushrooms [15].

The abundant protein in mushrooms has good antioxidant, antitumor and immunomodulatory activities. So mushroom proteins have good product development potential. Protein in mushrooms can be extracted enzymatically. The essential amino acids of the obtained Pleurotus eryngii protein accounted for $40 \%$ of the total amino acid content of Pleurotus eryngii protein powder. The ratio of essential amino acids to non-essential amino acids is 0,65 . Pleurotus eryngii protein is an ideal protein. The amino acid ratio coefficient of the protein product is 75,02 , which is significantly higher than that of soybean protein 61,22 . The obtained protein has high quality and can be used for industrial production of Pleurotus eryngii protein products [16].

Setting objectives. Sausages are traditional meat products. They are very popular in many countries. However, meat contains cholesterol and a higher proportion of saturated fatty acids than polyunsaturated fatty acids (PUFAs). It has been found that reducing the intake of red meat and meat products will reduce the incidence of cancers such as rectal and breast cancer [17]. Obviously, from a health point of view, excessive intake of meat products is not advisable, especially for some people with high fat content. On the other hand, meat is usually more expensive than vegetables. Therefore, more and more people are inclined to low-fat meat or vegetarian [18].

Presentation of the main research material. As a ready-to-eat product sausages are very popular with consumers due to its convenient consumption and long shelf life and its consumption is huge every year. Traditional sausages use meat as the main raw material and contain additives such as nitrite and phosphate. Long-term consumption will bring hidden dangers to human health. Vegetarian foods are becoming more and more popular with consumers. Mushrooms are rich in nutrients and are known as "plant meats" and have become a trend food in the United States. In United Kingdom was introduced "vegan steak". It was made entirely of mushrooms, has no meat and very popular locally. In China the eating mushrooms daily are considered a healthy diet.

However, fat plays an important role in the quality of sausages. By stabilizing meat emulsions, fats can reduce the cooking loss of sausages, improve water retention capacity, provide juiciness and hardness, and affect the quality and acceptability of sausages (flavor, texture, taste, etc.). Generally, low fat sausage production have problems with poor texture, bad taste and mouthfeel. So, the way to find a suitable fat substitute has become a hot spot for researchers. At present, there are many studies about dietary fiber, isolated soybean protein, carrageenan, $\beta$-glucan, starch, oat maltodextrin and konjac as fat and meat substitutes, that improve the rheological properties and stability of low-fat meat products and attempts to eliminate product quality issues caused by fat and meat reduced [19]. 
Dietary fiber has gel properties. Adding of dietary fiber to meat will reduce cooking losses, change $\mathrm{pH}$, and increase emulsion stability, thereby improving the cooking yield of emulsion-based meat products. Therefore, dietary fiber-rich raw materials can replace fats in sausages [20].

Chia and oat emusion gels used as animal fat replacers in reduced-fat fresh sausages can lower cooking loss, significantly affect the microbial count in the sausage [21]. Konjac gel as pork backfat replacer in dry fermented sausages can increase hardness and chewiness and decrease cohesiveness of sausages [22]. Response surface methodology can be used to optimize the process conditions for making low-fat sausages with oat flour instead of fat [23]. Furthermore, oat flour and carrageenan can be used in low-fat Frankfurters formulated [24], grain and fruit fiber can be used in low-fat dry fermented sausages, adding $1,5 \%$ fruit fiber can achieve a sensory quality similar to traditional high-fat products [25].

Replacing pork with $25 \%$ hydrated oats or $25 \%$ tofu can improve the acceptability of low-fat pork sausage [26], bulgur as meat replacement can be used in dry-fermented formulation [27].

It is possible to replace animal fats with plant oils, flaxseed oil is healthier than animal fat and can be used as an alternative to animal oils. Different ways of adding flaxseed oil will affect the basic properties of sausages, and affect how water and fat are bound, encapsulated flaxseed oil has the most significant effect on the physical properties of chicken sausage [28].

The main functions of proteins in meat sausages are gelling and related properties (e.g. meat particle binding and adhesion), emulsification and water retention. Vegetable protein also has this property, but the price of vegetable protein is lower than that of muscle protein. It can reduce the cost of sausage products. Moreover, many underdeveloped countries lack animal protein, which makes people increasingly accept lower-priced vegetable protein. Meat protein substitutes have also become research hotspots.

Protein rich in mushrooms is a high-quality protein containing all essential amino acids. The protein digestibility-corrected amino acid score is 0,91 . The nutritional value is equivalent to that of meat. Meanwhile, mushrooms are rich in polysaccharides and polyphenols content. It can increase sausage oxidation stability, so mushrooms are a good and economical alternative to meat protein in sausage [29].

Oyster mushroom and glutinous rice was used to replace the pork of traditional Thai fermented sausage. The resulting sausage is superior to traditional fermented sausage in terms of calorific value and microbial standards when the ratio of mushroom to glutinous rice is 40:60 [30]. Partial replacement of meat in sausages with boiled mushrooms or fried mushroom powder can reduce the amount of soy protein in sausages and the calories in sausages [31].

Adding mushrooms to sausages improves the physical properties, nutritional value and antioxidant capacity of sausages. Straw mushroom can improve the physical properties of meat sausage, reduce its peroxide value, increase the content of protein and essential amino acids, and the $\mathrm{P} / \mathrm{S}$ ratio of fatty acids in sausage [32]. Shiitake added to the sausage as a substitute for some lean meat can increase the moisture, total dietary fiber, methionine, glutamic acid, cysteine and total phenol content and the antioxidant activity of sausage [33]. Adding Shiitake mushroom powder to the low-salt chicken sausage can increased the $\mathrm{pH}$ of the meat paste, suppress fat oxidation, and not destroy the color and sensory properties of the sausage. The Shiitake mushroom powder can be used as a natural raw material to improve the quality of low-salt chicken sausage [34]. Adding sun mushroom powder can increase the oxidative stability of pork sausages [35], 2,0\% sun mushroom ethanol extract significantly improved the oxidative stability of pork sausages, which can be stored at $4{ }^{\circ} \mathrm{C}$ for 21 days [36].

The application of mushrooms in sausages discussed above is only using mushrooms as auxiliary ingredients. The addition of mushrooms is only a quality improver for traditional sausages, and meat is still the main ingredient. Compared with ordinary sausages, sausages with fresh mushrooms as the main material have many advantages in terms of nutrition, safety, cost and processing as mushrooms do not contain cholesterol and have low saturated fat content and high protein content [37].

Some literature reported on mushroom sausage, but most of the relevant studies were using meat as the main raw material. The purpose of adding mushrooms to sausage was to improve the flavor, the nutritional value and health function of the sausage. Mushroom tissue is brittle and tender, rich in polysaccharides, proteins and other biological macromolecules, so it is easier to crush and process into sausagelike gelatinous foods. In order to make efficient use of mushrooms, it is a good way to using mushrooms as the main raw material to make a new type of vegetarian sausage with the appearance and texture similar to that of traditional meat sausage. The new mushroom sausages have high additional value, nutrition and health care functions and will have a good development prospect. 
Conclusions. Deep processing of mushrooms and increasing the additional value of mushrooms have become the focus of domestic and foreign market competition. The future development of mushroom deep processing should focus on the research and development of mushroom functional foods and ready-to-eat foods.

At present, the main product forms of mushrooms in China are dried and canned. The largest export volume of Chinese mushroom products is also canned mush- rooms. The ready-to-eat product market has a single product category and few well-known brands, the market for mushroom ready-to-eat food is huge in the future.

Development of mushroom instant food like mushroom sausage will increase the variety of mushroom deep-processing products, increase the additional value of mushrooms, and help to solve the contradiction between production and marketing of mushrooms, so the development of mushroom sausage has great economic and social value.

\section{References:}

1. Yaoqi Zhang, Wei Geng \& Yueqin Shen. Edible Mushroom Cultivation for Food Security and Rural Development in China. Bio-Innovation, Technological Dissemination and Marketing. Sustainability. 2014. № 6. P. 2961-2973. doi: 10.3390/su6052961.

2. Himanshi Rathore, Shalinee Prasad \& SatyawatiSharma Mushroom nutraceuticals for improved nutrition and better human health: A review. Pharma Nutrition. 2017. № 5(2). P. 35-46. Doi: org/10.1016/j. phanu.2017.02.001.

3. Hans-Peter Hanssen. Determination of some Important Flavour Compounds in Commercial Mushroom Concentrates. Z Lebensm Unters Forsch. 2003. № 177. P. 333-335. Doi: org/10.1007/BF01042191.

4. Szabó A., Geösel A., Kókai Z., Orbán C., Töreki K. \& Szőke A. Antioxidant activity as indicator of UV radiation and other abiotic stress factors on Agaricus bisporus (Lange/Imbach) and Sedum hybridum (L.). Acta Universitatis Sapientiae, Alimentaria. 2016. № 9(1). P. 90-100. Doi: 10.1515/ausal-2016-0009.

5. Li B., Lu F., Suo X., Nan H. Antioxidant properties of cap and stipe from Coprinus comatus. Molecules. 2010. № 15(3). P. 1473-1486. Doi: 10.3390/molecules15031473.

6. Van Doan H., Doolgindachbaporn S. \& Suksri A. Effects of Eryngii mushroom (Pleurotus eryngii) and Lactobacillus plantarum on growth performance, immunity and disease resistance of Pangasius catfish (Pangasius bocourti, Sauvage 1880). Fish physiology and biochemistry. 2016. № 42(5). P. 1427-1440. Doi:10.1007/ s10695-016-0230-6.

7. Guillamon E., Garcia-Lafuente A., Lozano M., D'Arrigo M., Rostagno M., Villares A. \& Martinez J.A. Edible mushrooms: role in the prevention of cardiovascular diseases. Fitoterapia. 2010. № 81(7). P. 715-723. Doi: $10.1016 /$ j.fitote.2010.06.005.

8. Ren Z., Li J., Song X., Zhang J., Wang W. \& Jia L. The regulation of inflammation and oxidative status against lung injury of residue polysaccharides by Lentinula edodes. International journal of biological macromolecules. 2018. № 106. P. 185-192. Doi: 10.1016/j.ijbiomac.2017.08.008.

9. Gunawardena D., Shanmugam K., Low M. \& Munch G. Determination of anti-inflammatory activities of standardised preparations of plant- and mushroom-based foods, European journal of nutrition 2014; 53(1): 335-343. Doi: 10.1007/s00394-013-0531-9.

10. Doymaz I. Infrared drying of button mushroom slices. Food Science and Biotechnology. 2014. № 23(3). P. 723-729. Doi: 10.1007/s10068-014-0098-0.

11. Kantrong H., Tansakul A. \& Mittal G.S. Drying characteristics and quality of shiitake mushroom undergoing microwave-vacuum drying and microwave-vacuum combined with infrared drying. Journal of food science and technology. 2014. № 51(12). P. 3594-3608. Doi: 10.1007/s13197-012-0888-4.

12. Giavasis I. Bioactive fungal polysaccharides as potential functional ingredients in food and nutraceuticals. Current opinion in biotechnology. 2014. № 26. P. 162-173. Doi: 10.1016/j.copbio.2014.01.010.

13. Synytsya A., Jablonsky I., Slukova M. \& Čopikova J. Mushrooms of Genus Pleurotus as a Source of Dietary Fibres. Czech J Food Sci. 2008. № 26(6). P. 441-446. Doi: 10.17221/1361-CJFS.

14. Wenhang Wang, Guanhua Du, Xiuling Zhang \& Hongjie Zhang. Characteristics and Rheological Properties of Polysaccharide Nanoparticles from Edible Mushrooms (Flammulina velutipes). Journal of food science. 2017. № 82(3). P. 687-693. Doi: 10.1111/1750-3841.13626.

15. Kalaras M.D., Richie J.P., Calcagnotto A, Beelman RB. Mushrooms: A rich source of the antioxidants ergothioneine and glutathione. Food chemistry. 2017. № 233. P. 429-433. Doi: 10.1016/j.foodchem.2017.04.109.

16. Zhang Mengtian, Pei Fei, Zhao Liyan \& Qiuhui H.U. Optimization of Enzymatic Hydrolysis for Preparing Pleurotus eryngii Protein by Response Surface Methodology and Nutritional Evaluation. Food Science. 2015. № 36(13). P. 125-130. 
17. Diallo A., Deschasaux M., Latino-Martel P. \& Touvier M. Red and processed meat intake and cancer risk: Results from the prospective Nutr iNet-Santé cohort study. International Journal of Cancer. 2018. № 142(2). P. 230-237. Doi: 10.1002/ijc.31046.

18. Haverstock K. \& Forgays D.K. To eat or not to eat. A comparison of current and former animal product limiters. Appetite. 2012. № 58(3). P. 1030-1036.

19. Tahmasebi M., Labbafi M., Emam-Djomeh Z. \& Yarmand M.S. Manufacturing the novel sausages with reduced quantity of meat and fat: The product development, formulation optimization, emulsion stability and textural characterization. LWT - Food Science and Technology. 2016. № 68. P. 76-84.

20. Verma A.K. \& Banerjee R. Dietary fibre as functional ingredient in meat products: a novel approach for healthy living - a review. Journal of food science and technology. 2010. 47(3). P. 247-257.

21. Pintado T., Herrero A.M., Jimenez-Colmenero F., Pasqualin Cavalheiro C. \& Ruiz-Capillas C. Chia and oat emulsion gels as new animal fat replacers and healthy bioactive sources in fresh sausage formulation. Meat science. 2018. № 135. P. 6-13. Doi: 10.1016/j.meatsci.2017.08.004.

22. Ruiz-Capillas C., Triki M., Herrero A.M., Rodriguez-Salas L. \& Jimenez-Colmenero F. Konjac gel as pork backfat replacer in dry fermented sausages: processing and quality characteristics. Meat science. 2012. № 92(2). P. 144-150.

23. Choi J-W., Kim S-H., Mun S., Lee S-J. \& Kim Y-R. Optimizing the replacement of pork fat with fractionated barley flour paste in reduced-fat sausage. Food Science and Biotechnology. 2011. № 20(3). P. 687-694.

24. Troy Scehdj. Effects of oat fibre and carrageenan on the texture of frankfurters formulated with low and high fat. Eur Food Res Technol. 2000. № 211. P. 19-26.

25. Garcia M.L., Galvez M.D., Casas C. \& Selgas M.D. Utilization of cereal and fruit fibres in low fat dry fermented sausages. Meat science. 2002. № 60(3). P. 227-236. Doi: 10.1016/S0309-1740(01)00125-5.

26. Yang H.S., Choi S.G., Jeon J.T., Park G.B.\& Joo S.T. Textural and sensory properties of low fat pork sausages with added hydrated oatmeal and tofu as texture-modifying agents. Meat science. 2007. 75(2). P. 283-289.

27. Bayram M. \& Bozkurt H. The use of bulgur as a meat replacement: bulgur-sucuk (a vegetarian dry-fermented sausage). Journal of the Science of Food and Agriculture. 2007. № 87(3). P. 411-419.

28. Bolger Z., Brunton N.P. \& Monahan F.J. Impact of inclusion of flaxseed oil (pre-emulsified or encapsulated) on the physical characteristics of chicken sausages. Journal of Food Engineering. 2018. № 230. P. 39-48.

29. Asgar M.A., Fazilah A., Huda N., Bhat R. \& Karim A.A. Nonmeat Protein Alternatives as Meat Extenders and Meat Analogs. Comprehensive Reviews in Food Science and Food Safety. 2010. № 9(5). P. 513-529.

30. Suwimol Chockchaisawasdee S., Singdong Pochana \& Costas E. Stathopoulos. Development of fermented oyster-mushroom sausage. As J Food Ag-Ind. 2010. № 3(1). P. 35-43.

31. Stepanova T., Kondratjuk N., Haijuan N. \& Suprunenko K. Prospects of cultivated mushrooms use in technology of sausages. Bulletin of the National Technical University "KhPI" Series: New solutions in modern technologies. 2019. 10(2). P. 75-80. Doi: org/10.20998/2413-4295.2019.02.11.

32. Wang X., Zhou P., Cheng J., Chen Z. \& Liu X. Use of straw mushrooms (Volvariella volvacea) for the enhancement of physicochemical, nutritional and sensory profiles of Cantonese sausages. Meat science. 2018. № 146. P. 18-25.

33. Wang L., Guo H., Liu X. \& Li Y. Roles of Lentinula edodes as the pork lean meat replacer in production of the sausage. Meat science. 2019. № 156. P. 44-51.

34. Kyung Jo J.L. \& Samooel Jung. Quality Characteristics of Low-salt Chicken Sausage Supplemented with a Winter Mushroom Powder. Korean journal for food science of animal resources. 2018. № 38(4). P. 768-779.

35. Flavia Santi Stefanello \& Ernesto Hashime Kubota. Oxidative and microbiological stability of fresh pork sausage with added sun mushroom powder. Cienc Agrotec, Lavras. 2015. № 39(4). P. 381-389.

36. Stefanello F.S., Cavalheiro C.P., Ludtke F.L. \& Kubota E.H. Effect of sun mushroom extract in pork sausage and evaluation of the oxidative and microbiological stability of the product. Semina: Ciências Agrárias. 2015. № 36(1). P. 171-185.

37. Fei Lu, Xinxue Li \& Bo Li. Effect of Edible Gums on the Qualities of Sausage of Pleurotus eryngii. Advance Journal of Food Science and Technology. 2014. № 6(8). P. 973-980.

\section{Нан Хайцзюнь, Лі Бо, Степанова Т.М. АКТУАЛЬНІСТЬ ЗАСТОСУВАННЯ КУЛЬТИВОВАНИХ ГРИБІВ У ХАРЧУВАННІ ТА ПЕРСПЕКТИВИ ЗАСТОСУВАННЯ В КОВБАСНОМУ ВИРОБНИЦТВІ}

Стаття присвячена дослідженню перспектив використання культивованих грибів у харчових продуктах загалом і ковбасному виробництві зокрема. Звертається увага на швидке зростання виробництва грибів у Китаї. Зазначається, що завдяки багатій харчовій цінності та функціональним властивостям гриби стають все більи популярними серед споживачів. 
У статті звертається увага на те, щзо через функиіональні складники грибів, такі як протеїни, полісахариди, поліпептиди, тритерпени, можна віднести їх до нутрацевтиків. Багаті на білки гриби можуть бути гарними антиоксидантами та володіти протипухлинними та імуномодулюючими властивостями. Численні дослідження щодо структури та функиіональних властивостей білків, полісахаридів грибів вказують на те, щзо ие перспективний комериійний продукт для здорового харчування.

Гриби широко використовувалися у харчуванні завдяки унікальному смаку, аромату, високій харчовій иінності та корисності для здоров'я. Найпоширенішими продуктами переробки грибів є сухі продукти та консерви.

Гриби багаті нутріснтами, через які їх ще називають «рослинним м'ясом», і можуть бути досить популярними. Їх також можна представити як «веганські стейки», що виготовлені повністю з грибів і не містять у своєму складі м'яса. Щоденне вживання грибів, зокрема в Китаї, вважається здоровим харчуванням.

Додавання грибів у ковбасні вироби може замінити м'ясні білки та жири й матиме антиоксидантну дію. Крім того, одним із перспективних шляхів використання грибів є їх додавання у харчові продукти для збільшення смаку та харчової иінності. Ковбасна продукиія з використанням грибів як основної сировини є одним із перспективних напрямів переробки иієї цінної сировини. Це дозволить збільшити різноманітність продуктів глибокої переробки грибів, надасть додаткової цінності грибам і допоможе вирішити протиріччя між виробничтвом і збутом грибів, тому це має значне економічне та сочіальне значення.

Ключові слова: культивовані гриби, харчова цінність, нутрацевтики, функиіональні полісахариди, ковбасна продукиія. 